\title{
Audit committee gender diversity and financial reporting: evidence from restatements
}

Javad Oradi ${ }^{1}$, Javad Izadi

\begin{abstract}
Purpose - The main purpose of this study is to investigate the association between gender diversity on audit committees and the incidence of financial restatements.

Design/methodology/approach - Using a sample of 683 firm-year observations from Iranian listed companies for the period from 2013 to 2017, this paper uses a logistic regression model to examine a research hypothesis related to the association between the presence of female directors on the audit committee and the incidence of financial restatements.
\end{abstract}

Findings - After controlling for other restatement-related factors, we found that the presence of at least one female director on audit committees reduces the likelihood of the incidence of financial restatements. Robustness tests also confirmed this result. Moreover, we found that independent and financial expert female directors on audit committees are more strongly associated with a reduction in financial restatements. Finally, our additional analysis suggests that, in firms with gender diversity on audit committees and also the presence of independent and financial expert female directors, the likelihood of hiring auditors of a higher quality increases. Generally, the findings are consistent with the literature on gender diversity which suggests that women perform better in a monitoring role, are more conservative and make more ethical decisions.

Practical implications - The findings of this study could help with the understanding of broader participation of female directors on company boards and subgroups such as the audit committee, and of the improvement in corporate governance. Moreover, the findings can be of particular interest to monitoring authorities and policy makers in developing countries and send positive signals to them regarding the recommendation or requirement of gender diversity as a part of corporate governance mechanisms.

1) Javad Oradi, Faculty of Economic and Administrative Sciences, Ferdowsi University, Mashhad, Iran, Email:ja_oradi@mail.um.ac.ir

2) Javad Izadi, the Claude Littner Business School. University of West London (United Kingdom).

Corresponding author: Javad Izadi

University of West London, London, TW8 9GA, E-Mail: Javad.Izadi@uwl.ac.uk 
Originality/value - The present study contributes to the extant literature by providing empirical evidence on the effect of audit committee gender diversity on financial restatements. Furthermore, this study provides evidence on the more effective oversight and greater ability of independent female directors and financial expert female directors, respectively; which has been significantly disregarded in the previous studies.

Keywords: Corporate governance, Audit committee gender diversity, Financial reporting, Restatement, Iran.

\section{Introduction}

The increasing prevalence of financial restatements has been given considerable attention by academia (Plumlee \& Yohn, 2010). From the perspective of investors, restatements not only indicate problems of the previous period but also anticipate upcoming problems of the company and its management, which signal significant financial reporting weaknesses and can induce extreme market reaction (Akhigbe et al., 2005). In this regard, there is a growing research which demonstrates that good corporate governance can lead to a reduction in financial restatements and an improvement in financial reporting quality (e.g., Beasley, 1996; Abbott et al., 2004; Agrawal \& Chadha, 2005; Abdullah et al., 2010). Audit committees as one of the most important corporate governance mechanisms, play a major role in improving the corporate performance and economic earnings (Anderson et al., 2004, Davidson et al., 2004; Dey, 2008) and ensure financial reporting quality (Klein, 2002). Moreover, audit committees monitor the internal controls and the risk management processes (Klein, 1998; Krishnan, 2005; Zhang et al., 2007), and also enhances the external auditor's independence and audit quality (Krishnan \& Visvanathan, 2009; Chan et al, 2013; Soltana et al., 2015).

Some of the audit committee characteristics such as financial expertise and independence are vital for their effectiveness (e.g., Klein, 2002; Abbott et al., 2004; Krishnan, 2005). Nonetheless, gender diversity on the boards of directors and committees has also recently been considered as one of the factors which enhance their effectiveness (see, Chen et al., 2016; Lai et al., 2017; Aldamen et al., 2018). Female directors on the boards could both help improve the quality of decisions, provide the board of directors with a boost in their ability to monitor corporate disclosure and reports (Carter et al., 2010; Adams \& Ferreira, 2009; Gul et al., 2011) and affect the degree of risk aversion and conservatism when making decisions and monitoring the management (Thiruvadi \& Huang, 2011). Additionally, recent research has revealed that gender diversity can carry out functions for corporate governance and can be a potential factor in the activities and independence of the board of directors (e.g., Huse \& Solberg, 2006; Huse et al., 2009; Adams \& Ferreira, 2009; Abbott et al., 2012). This literature demonstrates that the presence of female directors on the board and its subgroups, such as the audit committee, is not only a matter of gender equality but is also a matter of corporate governance demanding sufficient consideration (Aldamen et al., 2018). 
Soltana et al. (2015) argue that gender differences on the audit committee may ruin the activity of the small group, leading to the formation of a majority and minority in the group and a decline in the effectiveness of the audit committee. In contrast, gender diversity on audit committees composition and the presence of experienced members with different ideas can help the audit committee with a wide range of accounting issues, thereby leading to the reduction of fraud opportunity and financial misstatements (Gul et al., 2011). However, Chen et al. (2016) noted that some companies may appoint female directors with the intention of merely lessening criticism. They investigated the effects of board gender diversity on internal control weaknesses and provide evidence concerning the failure of critical mass theory. According to critical mass theory, female directors are not able to produce any changes unless their numbers reach a certain threshold (e.g., three female directors). In this study, we also attempt to provide evidence regarding the credibility of critical mass theory through investigating the relationship between gender diversity on the audit committee, one of the important subgroups of the board of directors (Kelin, 1998; Xie et al., 2003), and financial restatement.

Prior literature documents evidence of the relationship between the presence of female directors on the board and firm-specific variables such as firm value (Carter et al., 2003), return on equity (Ming \& Eam, 2016), earnings quality (Srinidhi et al., 2011), earnings management (Arun et al., 2015), improvement of the informativeness of stock prices (Gul et al., 2011) and internal control weaknesses (Chen et al., 2016). In addition, the relationship has been confirmed between the presence of female directors on the audit committee with audit fees (Ittonen et al., 2010; Harjoto et al., 2015; Aldamen et al., 2018; Lai et al., 2017), auditor choice (Lai et al., 2017) and earnings quality (Thiruvadi \& Huang, 2011).

Furthermore, the association between the presence of female directors on boards and corporate performance has been reviewed in prior studies. Some studies have suggested that gender diversity on the board of directors has a positive relationship with corporate performance (Luckerath, 2010; Campbell \& Minguez-Vera, 2008), whereas other studies have found a negative relationship (Bohren \& Strom, 2010; Adams \& Ferreira, 2009) with some other research finding no relationship (Chapple \& Humphrey, 2014; Carter et al., 2010). These mixed results leave the issue of improving organizational performance through gender diversity remaining unsolved, despite the huge extant literature. Nevertheless, female members appear interested in discussing difficult issues (Chen et al., 2016), are more conservative about financial issues (Francis et al., 2015) and play the oversight role successfully (Adams \& Ferreira, 2009) and appear less tolerant towards opportunistic behavior (Thorne et al., 2003); it can be expected, therefore, that companies with female members on the board of directors and on its subgroups such as the audit committee increase financial reporting quality via reducing mistakes and restatements. Moreover, female members on audit committees appear to desire audit information of a higher quality (Aldamen et al, 2018) and this can reduce auditor failure to detect mistakes as one of the factors which increases restatements (Czerney et al., 2014).

In some countries, audit committees are either required by law (such as in Canada, Singapore and Thailand), mandated by regulators (such as Bangladesh, Malaysia and the U.S.), or are highly recommended by the code of best practice (e.g., Britain). In many countries, audit committees are not compulsory but companies can constitute audit 
committees voluntarily. In Iran, the internal control instruction was approved in May 2012 and communicated in February 2013. Based on this instruction, companies listed on the Tehran Stock Exchange (TSE) are required to constitute audit committees (TSE, 2013). Therefore, considering the fact that audit committees are in their early stage of development in Iran and that the effectiveness of audit committee has a significant effect on minimizing agency conflicts, safeguarding shareholders' interests and maximizing the total value of firms (Zahra \& Pearce, 1989; Dey, 2008), we investigated the effect of effective audit committee on financial statement restatements in Iranian firms through gender diversity characteristics (Ittonen et al., 2010; Thiruvadi \& Huang, 2011; Harjoto et al., 2015; Aldamen et al., 2018). Prior research in Iran shows that the high percentage of Iranian companies restates their financial statements in order to correct accounting mistakes (e.g., Kordestani et al., 2011; Nickbakht \& Rafiee, 2013). This can bring the reliability of the accounting information of such companies into doubt. Using the data on 683 firm-year observations in the TSE during the period 2013-2017, we found that the presence of at least one female director on audit committee reduces the likelihood of the incidence of financial restatements. Robustness tests also confirmed this result. Moreover, we found that independent and financial expert female directors on audit committee are more strongly associated with the reduction in financial restatements. Finally, our additional analysis suggests that, in firms with gender diversity on the audit committee and also the presence of independent and financial expert female directors, the likelihood of hiring auditors of a higher quality increases. Overall, our findings reveal that mandating the constitution of audit committees and subsequently the presence of female directors on these committees could reduce restatements and enhance the reliability of financial statements in Iran.

This study contributes to the accounting literature in several ways. First, this study contributes to the evolving literature on gender diversity and financial restatements. Prior research examined the relationship between audit committee characteristics (such as independence, size, expertise, and the frequency of audit committee meetings) and financial restatements (Abbott et al., 2004; Carcello et al., 2011; Lary \& Taylor, 2012, Mohammad et al., 2018). Furthermore, Abbott et al. (2012) and Wahid (2018) studied the effect of board gender diversity on financial restatements. Nonetheless, the question of whether the presence of women on audit committee is associated with restatements remains unsolved. Whilst the ultimate responsibility for financial reporting rests with the board of directors, the routine responsibility and accountability for the financial reporting process within the firm increasingly devolves upon the audit committee which is widely believed to be the most important subgroup of the board (Xie et al., 2003). The audit committee is expected to serve a pivotal role in assuring the quality of financial reporting. For this reason, a huge number of previous studies on restatements and fraud have brought audit committees into focus of attention (either in place of or added to/along with the full board) (Abbott et al., 2012). Additionally, Adams and Ferreira (2009) found that female members on the board are more likely to join supervisory committees. Therefore, it seems that special focus on gender diversity on audit committees and its effect on financial reporting is of great importance.

Second, the importance of our study is beyond bridging the existing gap in the literature, as we witness the growing trend towards the presence of female members (Chen et al., 2016) and the tendency in global markets towards voluntary or mandatory recruitment of 
female members on boards (Usman et al., 2018a). Some countries (e.g., Australia, Canada and Britain) recommended the participation of women on the board of directors and some other countries (e.g., Belgium, France, Netherlands, Italy, Norway and Spain) require the presence of women on the boards (Aldamen et al., 2018). Thus, reviewing and understanding how female directors participate on the board and its subgroups such as the audit committee is necessary for corporate governance improvement and can provide empirical evidence on the effectiveness of women in such groups for global markets. Specifically, the evidence of the present study may be of use to supervisors and policy makers in developing countries and send positive signals to them regarding the recommendation or requirement of gender diversity as a part of corporate governance mechanisms.

Third, in contrast to developed countries, the corporate governance structure in Iran is weak (Bagherpour et al., 2014). For instance, in countries like the U.S., all members of the audit committee must be independent, while there is no such requirement in Iran where there is a combination of female executives and independent female directors on audit committees. Therefore, this provides a unique opportunity to investigate whether independent female directors on audit committees play a prominent role in financial reporting. Furthermore, investigating the role of financial expert female directors on audit committees could be of interest. Our findings showed that the relationship between gender diversity on audit committees and financial restatements is stronger when female directors have independence and financial expertise. These findings contribute to the extant literature and provide new evidence on the more effective oversight and greater ability of independent female directors and financial experts respectively, compared to female executives and female directors who lack financial expertise. Previous studies have reviewed the role of female directors in corporate governance, but the suggestion that independent and financial expert female directors may perform their oversight function more effectively with greater ability has been disregarded (see, Adams \& Ferreira, 2009; Gul et al., 2011; Aldamen et al., 2018). Finally, our findings are similar to those of Chen et al. (2016) and are inconsistent with critical mass theory, because we show that the presence of, at the very least, one female member on the audit committee reduces the likelihood of financial restatement and improves the financial reporting quality. This is highly important, owing to the fact that several studies such as Joecks et al. (2013) and Torchia et al. (2011) support critical mass theory in settings of firm performance and corporate innovation.

The rest of the paper is organized as follows: Section 2 provides a background to the Iranian context. Section 3 reviews the theoretical literature and Section 4 reviews the empirical literature and develops the research hypothesis. Section 5 presents the research design and consecutively the research model and definitions of the research variables. Section 6 presents the empirical results and discussion. The summary and conclusion are provided in Section 7.

\section{Institutional background}

Tehran Stock Exchange (TSE) is the largest capital market in Iran. TSE first opened in 1968 and is a member of Federation of Euro-Asian Stock Exchanges. Regarding TSE's legal structure, the regulations and requirements of financial reporting are comparable with those of Western countries such as the U.S. (Hesarzadeh, 2018) or some European countries, 
especially in Eastern Europe (Mashayekhi \& Bazaz, 2008). For example the TSE, implementing regulations of great importance such as for financial reporting (e.g., internal control reports, M\&D reports, etc.) or for protecting investors (such as reports on suspicious transactions, irregularities and infractions, etc.), is enacting similar regulations to that of large capital markets such as in the U.S. (Hesarzadeh, 2018).

However, corporate governance in Iran is not yet well developed and Iranian companies have often met with criticism for their poor corporate governance mechanisms (Bagherpour et al., 2014; MohammadRezaei et al, 2018). In addition, prior research has demonstrated that there is a greater incidence of financial restatements in Iran when compared to developed countries such as the U.S. (e.g., Kordestani et al., 2011; Nickbakht \& Rafiee, 2013). This raised concerns for regulators facing a reduction in both the credibility of financial reports and confidence of investors in the financial statements, pushing them into taking measures to mitigate such risks. The adoption of the internal controls instruction in 2012 was one of the important steps to improve the quality of financial reports. Based on this instruction, TSE firms were required to set up an audit committee and other specialized committees and to provide arrangements that interact with the committees and the internal audit unit to establish and implement appropriate and effective internal controls (Oradi et al., 2016a). According to the audit committee charter, the majority of the committee members should have independence and financial expertise, but companies were not required to maintain gender diversity on audit committees. However, recent studies in Iran reveal that approximately 11 percent of companies ensured the presence of at least one woman on their audit committees (Imani et al., 2017). Hence, these new Iranian regulations and corporate governance characteristics offer an opportunity to conduct research: the present study investigates how audit committee gender diversity leads to reductions in financial restatements. Particularly, this study has important implications for regulators in the Iranian capital market who are looking at ways of reducing harmful issues in financial reporting and improving their corporate governance. Recent research on the TSE revealed that the constitution of audit committees has been associated with an increase in the transparency of information (Fakhari \& Rezaei, 2018) and the improvement of corporate performance (Oradi et al., 2016b). Particularly, Rezazadeh et al. (2017) suggest that audit committee characteristics (such as financial expertise and independence) are associated with a reduction in the restatement of financial statements. However, the research into gender diversity on audit committee is very limited in Iran.

\section{Theoretical literature review}

\subsection{Audit committee and restatement}

Restatement can be considered an important event which indicates poor quality financial reporting in previous periods [General Accounting Office (GAO), 2002]. Eilifsen and Messier (2000) consider four conditions for audited financial statements to be restated. Firstly, material misstatements by a company's due to some inherent risks (e.g., aggressive accounting practices of the management, misapplication of accounting principles and approaches, etc.). Secondly, misstatements are not detected and prevented by the internal controls. Thirdly, the external auditor fails to detect the misstatements and the financial statements are issued. Fourthly, the misstatements are detected after a while and, if they are 
significant, companies will be required to correct, restate and reissue financial statements. The urgent need for restatement arises when the first three conditions mentioned above are observed in the financial reporting process (Abbott et al., 2004). According to previous literature, restatements lead to the reduction of corporate value (Palmrose \& Scholz, 2004), a negative response on the stock price (Wilson, 2008; Chen et al., 2014), an increase in CEO/CFO turnover (Hennes et al., 2008) and litigation risk (Palmrose et al., 2004; Demirkan \& Fuerman, 2014). Furthermore, restatements can reflect on earnings management (Agrawal \& Chandha, 2005). Thus, considering the consequences of restatement, it is necessary to identify the factors that could reduce financial restatements.

Prior literature demonstrates that companies with strong corporate governance are more engaged in monitoring the financial reporting process (Abdollah et al., 2010) and companies who issue financial restatements suffer from a weak governance structure (Efendi et al., 2007). The board of directors and its subgroups such as the audit committee are the main governance mechanisms which play a major oversight role on behalf of shareholders. The significance of audit committee has been highlighted by corporate governance laws and regulations. For instance, according to Section 301 of the Sarbanes-Oxley (SOX) Act (2002), public companies are required to constitute audit committees. This law attempts to improve the quality of the financial reporting process (Carver, 2013). From the perspective of agency theory, audit committees fulfill a significant role in reducing agency problems (Zahra \& Pearce, 1989; Dey, 2008) and can lead to an improvement in financial reporting quality (Krishnan et al., 2011). In addition, an effective audit committee improves the quality of internal controls over financial reporting (Krishnan, 2005; Zhang et al., 2007) and enhances the value of the accounting information (Habib \& Azim, 2008). Moreover, McMullen and Raghunandan (1996) also suggest that companies with effective audit committees are less likely to face mistakes, irregularities, and fraudulent financial reporting.

\subsection{Gender diversity}

Gender theory holds that women have a significant part to play in economic success (Waring, 1988). Moreover, there are gender-based ethical differences. To illustrate these differences, the gender socialization theory of Dawson (1997) could be of great help. According to this theory, women exposed to different ethical developments, tend to hold different values leading to various outlooks and behavior. For instance, men may attach value to money, progress and power and be more willing to enter competitive situations, whereas women might pay more attention to social interactions, fulfill their assigned tasks more effectively, be more likely to comply with the regulations (Geiger \& Connell, 1999) and this may lead to the improvement of information (Carter et al., 2010). In addition, research on the field of group work points to the fact that gender diverse groups perform differently from samegender groups, due to the various experiences and beliefs gender diverse groups have. What is more, social diversity (gender, age and ethnic groups) may reduce intergroup communication, increase conflict of opinions and disagreements and consequently lead to the enhancement of the effectiveness of group decision-making (Ittonen et al., 2010).

Furthermore, prior research on gender diversity points to behavioral differences between males and females. For example, females may possess greater communication skills (Westphal \& Milton, 2000) and tend to ask the questions which men do not ask (Konrad et 
al., 2008). They may improve the decision making and the leadership style (Rosener, 1990) and pay more attention to qualitative issues such as social responsibility, humanitarianism (Hafsi \& Turgut, 2013), task orientation and compliance with rules and regulations (Geiger \& Connell, 1999). Women as compared to men may be more risk-averse (Beckmann \& Menkhoff, 2008; Bellucci et al, 2010; Thiruvadi \& Huang, 2011, Francis et al., 2015), make more conservative decisions (Schubert, 2006) and be less tolerant towards opportunistic behaviour (Krishnan \& Parsons, 2008). Furthermore, women may be less over-confident than men (Huang \& Kisgen, 2013). Wood et al. (1985) state that women who work in a group can put forward better solutions to a problem. They found that men come up with more solutions for a specific problem, but the solutions of a higher quality were often offered by women.

However, there are some concerns that firms may add female members to merely reduce criticism: female directors are only tokens (critical mass theory) (Chen et al., 2016). Prior research has removed this concern to a large extent and indicated that the presence of at least one female director on the board and on its subgroups such as the compensation committee and audit committee leads to improvement of corporate performance (e.g., Chen et al., 2016; Thiruvadi \& Huang, 2011; Usman et al., 2018a). In this study, we extend this research stream and explore how women on audit committees can impact financial restatements.

\section{Empirical literature review and hypothesis development}

Consistent with gender theory, prior literature suggests that women can play a major role in enhancing oversight, board performance and corporate output. Adams and Ferreira (2009) present evidence which points to the fact that women perform better in the monitoring role in top management. Bart \& McQueen (2013) suggest that women make better directors because they are more likely to take account of the interests of all stakeholders. The increase in the number of female directors on boards benefits the companies, shareholders and customers (Grosvold et al., 2007). Davis (2011) found that the presence of one female director on the board reduces the likelihood of bankruptcy by up to 20 percent and the presence of two or three of them could reduce it even more. Sial et al. (2018) concluded that gender diversity on the board results in the improvement of corporate performance. Also, they showed that corporate social responsibility modifies the relationship between gender diversity on the board and corporate performance. Moreover, Usman et al. (2018b) showed that female directors on the board are associated with the development of the CEO's power. Usman et al. (2018c) found that female CEOs lead to the reduction in cost of debt.

Furthermore, prior research provides evidence on the improvement of financial reporting quality as a result of the presence of female directors on the board. For instance; gender diversity on the board of directors is associated with the improvement of accruals quality (Srinidhi et al., 2011), the accuracy of financial analysts' earnings forecasts (Gul et al., 2013) and the quality of internal controls over financial reporting (Chen et al., 2016). Moreover, Barua et al. (2010) reported that companies with female CFOs have earnings of a greater quality and such companies are substantially associated with an improvement of accounting conservatism in the financial reporting (Francis et al., 2015).

Abbott et al. (2012) and Wahid (2018) argue that gender diversity on the board of directors could result in the board making decisions of a higher quality through an increase in 
interactions and consideration of different points of the view. They found that gender diversity on the board of directors reduces the likelihood of the incidence of financial statements restatement. However, empirical evidence about the effect of audit committee gender diversity on financial restatements is sparse. Prior studies have focused on the role of other characteristics of audit committees on financial restatement. Using data from U.S. companies; Abbott et al (2004) and Carcello et al (2011) showed that there is a negative relationship between independence, frequency of meetings and financial expertise on audit committees and financial restatement. Using data from Australian companies; Lary and Taylor (2012) revealed that audit committee independence reduces the incidence and intensity of financial restatements. Further, Mohammad et al. (2018) based on a sample of Malaysian companies; found that there is a negative relationship between independence, frequency of meetings, financial expertise, and the size of audit committees and financial restatements.

Despite the significant role of the audit committee and the necessity for an increase in diversity in audit committee composition, the research conducted in this context is relatively limited. Thiruadi and Huang (2011) stated that the presence of female directors on audit committees improves the quality of operating the audit committee in terms of external performance, and reduces earnings management. Ittonen et al. (2010) and Harjoto et al. (2015) suggest that audit committees with female members are associated with lower audit fees. These authors state that female directors may lower audit fees by affecting auditor assessment of audit risk (by improving communication with auditors or by improving internal oversight effectiveness and increasing the accuracy of the financial reporting process). On the contrary, Aldamen et al. (2018) and Lai et al. (2017) reported that gender diversity on the audit committee leads to an increase in audit fees. They argue that women, owing to a higher level of conscience, seriousness and responsibility, seek for audits of a higher quality. Higher audit quality is associated with detecting material mistakes, thereby reducing restatements (Jiang et al., 2015).

Given gender theory, the literature discussed above and female characteristics such as task orientation, better monitoring ability, risk aversion and conservatism, and in line with the idea of an association between the reduction of restatements and the presence of women on the board of directors (Abbott et al, 2012, Wahid, 2018), we assume that the presence of female directors on audit committees strengthens the external governance of the firm and its auditor, reduces opportunistic behaviour of the management and mistakes and consequently reduces restatements. Therefore, the research hypothesis is as follows:

$H 1$ : There is a negative association between the presence of female director on the audit committee and the incidence of restatement.

\section{Research design}

\subsection{Sample and data}

The research sample comprises all the companies listed on the TSE in the period 2013-2017. The reason for choosing 2013 as the base year is the communication of the internal controls manual requiring the companies listed on the TSE to constitute an audit committee in the year 2013 (TSE, 2013). 
The data is collected from the annual reports of the companies listed on the Tehran Stock Exchange [1] and the Rahavard-e-Novin database [2]. The initial sample includes 1625 firm-year observations. The final sample decreases to 683 firm-year observations when financial firms and utilities are excluded due to the different nature of the operations of such firms (see, Hesarzadeh \& Bazrafshan, 2018). Moreover, we excluded the delisted firms and observations with insufficient information for measuring the variables. Table 1 outlines the sample selection procedure. All variables are winsorized at the 1st and 99th percentiles to reduce the influence of outliers on the regression results.

\subsection{Regression model}

We estimate the following logistic regression model for investigating the relationship between the presence of females on audit committees and the incidence of restatements:

$$
\begin{aligned}
& \text { Restate }_{i t}=\beta_{0}+\beta_{1} A c_{-} f d_{i t}+\beta_{2} A c_{-} \text {ind } p_{i t}+\beta_{3} A c_{-} \text {exp }_{i t}+\beta_{4} A c_{-} \text {size } e_{i t} \\
& +\beta_{5} \text { Board_size }_{i t}+\beta_{6} \text { Board_indp }_{i t}+\beta_{7} \text { CEOchair }{ }_{i t}+\beta_{8} \text { Conown }_{i t} \\
& +\beta_{9} \text { Instown }_{i t}+\beta_{10} \text { Stown }_{i t}+\beta_{11} \text { Mgrown }_{i t}+\beta_{12} \text { Age }_{i t} \\
& +\beta_{13} \text { Zscore }_{i t}+\beta_{14} \text { Leverage }_{i t}+\beta_{15} \text { Finance }_{i t}+\beta_{16} \text { Growth }_{i t} \\
& +\beta_{17} \text { ROA }_{i t}+\beta_{18} \text { Size }_{i t}+\beta_{19} \text { Accrual }_{i t}+\beta_{20} \text { Weak }_{i t}+\beta_{21} \text { Big }_{i t} \\
& +\beta_{22} \text { Spec }_{i t}+\text { Industry Dummies }+ \text { Year Dummies }+\varepsilon_{i t}
\end{aligned}
$$

Where, the dependent variable is restatement (Restate), which equals 1 if the financial statements of the firm are restated in the year $t$, otherwise 0. Our independent variable is gender diversity $\left(A c_{-} f d\right)$, which equals 1 if there is at least one female director on the audit committee, otherwise 0 (Ittonen et al., 2010; Aldamen et al., 2018). In line with prior research, we controlled for the variables related to the effectiveness of audit committee which are associated with the incidence of restatement (Abbott et al., 2004; Carcello et al., 2011; Lary \& Taylor; 2012). These variables include audit committee independence (Ac_indp), financial expertise (Ac_exp) and size (Ac_size) [3].

Furthermore, in accordance with prior research (Basely, 1996; Abbott et al., 2004), we controlled for the characteristics of the board of directors including size (Board_size), independence (Board_indp) and CEO duality (CEOchair) which could affect the incidence of restatement. Decentralized ownership can increase the likelihood of restatements (Defond \& Jiambalyo, 1991; GAO; 2002). In addition, previous studies demonstrate that there is a positive relationship between institutional ownership (Wahid, 2018) and state ownership (Wang \& Wu, 2011) and restatements. Further, Jiang et al (2015) show a negative relation 
between managerial ownership and restatements. Accordingly, we included the concentration of ownership (Conown), institutional ownership (Instown), state ownership (Stown) and managerial ownership (Mgrown) variables in the equation. Furthermore, firm age is associated with reporting problems; presumably as the firm age increases, the likelihood of restatement decreases, owing to the fact that young firms face problems which may lead to more restatements (Basely, 1996). Financial distress also increases the likelihood of opportunistic reporting by management and this leads to restatement (Jiang et al., 2015). Hence, firm age (Age) and financial distress (Zscore) are included in the equation. In the following, we include some firm-level financial variables as the determining factors in restatement in the equation (see, Abbott et al., 2004, Almer et al., 2008; Carcello et al., 2011; Abbott et al, 2012; Jiang et al., 2015; Zhang et al., 2018). These variables include Leverage, Finance, Growth, ROA, Size, Accrual. Plumlee and Yohn (2010) consider internal controls weakness as one of the determining factors in restatements. Thus, we controlled for internal controls weakness (Weak) in the equation. Furthermore, prior studies argue that, with the enhancement of audit quality and auditor's knowledge of the client's activity, the likelihood of restatement decreases (Chin \& Chi, 2009; Jiang et al., 2015). Therefore, we controlled for auditor size (Big) [4] and auditor industry speciality (Spec) variables as they are proxies for audit quality (DeAngelo, 1981; Dunn \& Mayhew, 2004). We also include industry and year dummy variables in all our regression specification. All the variables are defined in Table 2.

Table 2, Descriptions of variables

\begin{tabular}{|c|c|}
\hline Variable & Description \\
\hline \multicolumn{2}{|c|}{ Dependent variable } \\
\hline Restate & $\begin{array}{l}\text { An indicator variable with the value of } 1 \text { for firm-year observations with } \\
\text { restatement and } 0 \text { otherwise }\end{array}$ \\
\hline \multicolumn{2}{|c|}{ Independent variable } \\
\hline$A c \_f d$ & $\begin{array}{l}\text { An indicator variable with the value of } 1 \text { if there is at least one female } \\
\text { director on the audit committee, and } 0 \text { otherwise }\end{array}$ \\
\hline \multicolumn{2}{|c|}{ Control variables } \\
\hline Ac_indp & the proportion of independent female directors on the audit committee \\
\hline$A c \_$exp & The proportion of audit committee members with financial expertise \\
\hline Ac_size & The number of audit committee members \\
\hline Board_size & The number of board members \\
\hline Board_indp & The proportion of independent directors on the board \\
\hline CEOchair & $\begin{array}{l}\text { An indicator variable with the value of } 1 \text { if the CEO and chairman are the } \\
\text { same and } 0 \text { otherwise. }\end{array}$ \\
\hline Conown & $\begin{array}{l}\text { The proportion of a firm's outstanding shares that are owned by the largest } \\
\text { shareholder }(=>\% 5)\end{array}$ \\
\hline Instown & The proportion of shares held by institutional investors \\
\hline Stown & $\begin{array}{l}\text { An indicator variable which equals } 1 \text { if the government is the largest } \\
\text { shareholder }(=>\% 50)\end{array}$ \\
\hline Mgrown & The cumulative managerial share ownership \\
\hline Age & The natural logarithm of number of years the firm has been established \\
\hline Zscore & $\begin{array}{l}\text { Altman } \mathrm{Z} \text { Score to predict bankruptcy using the coefficients from the } \\
\text { original Altman formula. The higher the } \mathrm{Z} \text { score is, the lower the chance of } \\
\text { bankruptcy }\end{array}$ \\
\hline Leverage & Total debt divided by total assets \\
\hline Finance & $\begin{array}{l}\text { Operating cash flows minus average capital expenditures (it-3 to it-1), divided } \\
\text { by lagged current assets }\end{array}$ \\
\hline Growth & The proportion of change in annual sales revenue \\
\hline$R O A$ & Net income divided by total assets. \\
\hline
\end{tabular}


Size

Accrual

Weak

Big

Spec

Additional
$A c \_f p$
$A c \_f b i$
Ac_fsi
Ac_findp
Ac_fexp
Board_fp
Chta
Aturn
Curr
Quick
Loss

\section{Additional variables}

$A c_{-} f p$

$A c_{-} f b i$
The natural logarithm of total assets

Total accruals to sales, which is calculated as net income minus operating cash flows, divided by lagged assets

An indicator variable with the value of 1 if the auditor reports an internal control weakness for the ICFR audit of fiscal year $t, 0$ otherwise

An indicator variable with the value 1 if the auditor is a Big audit firm, and zero otherwise

An indicator variable with the value of 1 if the client's audit firm audits at least 20 percent of sales in the client's industry, and 0 otherwise (Casterella et al., 2004)

The proportion of female directors on the audit committee

The Blau index, which is measured as $1-\sum_{\mathrm{i}=1}^{\mathrm{n}_{\mathrm{i}}} P^{2}$, where $P_{i}$ is the proportion of each category and $n$ is the number of categories. In our case, $n$ is 2 and the categories are "male" and "female"

The Shannon index, which is measured as $-\sum^{\mathrm{n}}{ }_{\mathrm{i}=1} P_{i} \ln P_{i}$, where $P_{i}$ is the proportion of each category and $n$ is the number of categories. In our case, $n$ is 2 and the categories are "male" and "female"

An indicator variable with the value of 1 if there is at least one independent female director on the audit committee, and 0 otherwise

An indicator variable with the value of 1 if there is at least one financial expert female on the audit committee, and 0 otherwise

The proportion of female directors on the board

The proportion of change in total assets from the previous year

Asset turnover ratio, measured as sales divided by total assets

Current assets divided by total assets

Current assets minus inventory divided by current liabilities

An indicator that equals 1 when firm net income is negative, 0 otherwise

Note: This table defines the main variables. Furthermore, the table includes the definitions of additional variables, which is used for robustness tests and additional analyses at the end of the findings section.

\section{Empirical results and discussion}

\subsection{Descriptive statistics and correlations}

Table 3 provides descriptive statistics of variables for the complete sample (panel A) and firm-year observations in two groups with restatement and without restatement and differences in means (Panel B). Panel A of the Table 3 results show that 66.47 percent of the final sample including 683 firm-year observations, used in the final analysis, restated their financial statements. The percentage has considerably decreased in comparison with the research conducted on the TSE (Nikbakht \& Rafeei, 2012) showing that approximately 79 percent of the companies on the TSE restated their financial statements. In addition, this finding is notably higher than the mean of restatements in developed countries (e.g., Chen et al., 2016). The findings in panel $\mathrm{A}$ also show that the percentage of the presence of at least one female member on audit committees $\left(A c_{-} f d\right)$ of the sample firms is 12 which is close to the mean of the presence of at least one female member on audit committees in Australia (15 percent) (Aldamen et al., 2018).

Furthermore, Panel B of Table 3 indicates that the mean of the $A c \_f d$ in firms without restatements is significantly higher than that of firms with restatements. Moreover, Panel B demonstrates that, compared to the firms without restatements, firms with restatements have a higher CEO duality (CEOchair), state ownership (Stown), firm age (Age), growth of sales (Growth), firm size (Size) and internal control weaknesses (Weak). In contrast, firms without restatement, in comparison with firms with restatement, have a higher audit committee 
independence (Ac_indp), board of directors' independence (Board_indp), managerial ownership (Mgrown) and industry specialist auditor selection (Spec).

Table 4 reports Spearman's correlations between the variables used in the main analysis. Bold denotes significant correlation coefficients at the 10 percent level. The correlation between Restate and $A c_{-} f d$ is negative (-0.18) and statistically significant, indicating that audit committee gender diversity may be associated with financial restatement. The correlations between the other variables never exceed 50 percent, thus alleviating the concerns of the potential of multicollinearity affecting the results. To further check for the possibility of multicollinearity between the variables included in our model, we additionally calculated the variance inflation factors (VIF) for the independent variables. The VIF scores in all models (when estimated regressions) is below the acceptable threshold of 5, suggesting that multicollinearity is not a significant issue.

Table 3, Descriptive Statistics

\begin{tabular}{|c|c|c|c|c|c|c|}
\hline \multicolumn{7}{|c|}{ Panel A: Descriptive Statistics for the Full Sample ( $n=683)$} \\
\hline \multicolumn{7}{|c|}{ Descriptive statistics for continuous variables: } \\
\hline Variable & Mean & $\underline{\mathrm{SD}}$ & $\underline{\text { Min }}$ & Q1 & Q3 & Max \\
\hline$\overline{A c \_i n d p}$ & $\overline{0.727}$ & $0 . \overline{136}$ & $\overline{0.33}$ & 0.67 & 0.67 & $\overline{1.00}$ \\
\hline$A c \_$exp & 0.866 & 0.186 & 0.33 & 0.67 & 1.00 & 1.00 \\
\hline Ac_size & 3.149 & 0.520 & 3.00 & 3.00 & 3.00 & 5.00 \\
\hline Board_size & 5.112 & 0.391 & 5.00 & 5.00 & 5.00 & 7.00 \\
\hline Board_indp & 0.635 & 0.131 & 0.20 & 0.60 & 0.80 & 0.86 \\
\hline Conown & 0.813 & 0.140 & 0.36 & 0.73 & 0.92 & 0.99 \\
\hline Instown & 0.432 & 0.283 & 0.00 & 0.18 & 0.66 & 0.95 \\
\hline Mgrown & 0.207 & 0.288 & 0.00 & 0.00 & 0.51 & 0.91 \\
\hline Age & 3.548 & 0.398 & 2.64 & 3.26 & 3.91 & 4.14 \\
\hline Zscore & 2.251 & 1.647 & -0.89 & 1.20 & 2.96 & 9.22 \\
\hline Leverage & 0.558 & 0.208 & 0.07 & 0.42 & 0.71 & 1.05 \\
\hline Finance & 0.352 & 0.392 & -0.34 & 0.11 & 0.49 & 2.08 \\
\hline Growth & 0.429 & 1.644 & -0.94 & -0.06 & 0.38 & 11.55 \\
\hline$R O A$ & 0.134 & 0.150 & -0.23 & 0.03 & 0.21 & 0.74 \\
\hline Size (Ln assets) & 14.347 & 1.425 & 11.05 & 13.47 & 14.94 & 18.38 \\
\hline Accrual & 0.010 & 0.147 & -0.47 & -0.07 & 0.09 & 0.54 \\
\hline \multicolumn{7}{|c|}{ Descriptive statistics for dummy variables: } \\
\hline Variable & & Min & $\underline{\operatorname{Max}}$ & frec & ency 1 & $(\%)$ \\
\hline Restate & & 0 & 1 & & 54 & 66.47 \\
\hline$A c \_f d$ & & 0 & 1 & & 6 & 12.59 \\
\hline CEOchair & & 0 & 1 & & 41 & 20.64 \\
\hline Stown & & 0 & 1 & & 00 & 14.64 \\
\hline Weak & & 0 & 1 & & 13 & 31.18 \\
\hline Big & & 0 & 1 & & 59 & 23.25 \\
\hline Spec & & 0 & 1 & & 38 & 34.85 \\
\hline \multicolumn{7}{|c|}{ Panel B: Descriptive Statistics by Restate } \\
\hline & \multicolumn{2}{|c|}{$\begin{array}{c}\text { Restate }=1 \\
(\text { Observations }=454)\end{array}$} & \multicolumn{2}{|c|}{$\begin{array}{c}\text { Restate }=0 \\
(\text { Observations }=229)\end{array}$} & Differences & \\
\hline & $\underline{\text { Mean }}$ & $\underline{\text { Std. Dev. }}$ & $\underline{\text { Mean }}$ & $\underline{\text { Std. Dev. }}$ & $\underline{\text { in Means }}$ & p-value \\
\hline$A c \_f d$ & 0.081 & 0.273 & 0.213 & 0.411 & -0.132 & $0.000 * * *$ \\
\hline$A c \_$indp & 0.713 & 0.124 & 0.753 & 0.154 & -0.040 & $0.000 * * *$ \\
\hline$A c \_$exp & 0.858 & 0.189 & 0.883 & 0.178 & -0.025 & 0.103 \\
\hline Ac_size & 3.129 & 0.486 & 3.187 & 0.580 & -0.058 & 0.170 \\
\hline Board_size & 5.121 & 0.394 & 5.096 & 0.385 & 0.025 & 0.429 \\
\hline Board_indp & 0.629 & 0.137 & 0.648 & 0.117 & -0.019 & $0.076^{*}$ \\
\hline CEOchair & 0.231 & 0.422 & 0.157 & 0.364 & 0.074 & $0.023 * *$ \\
\hline Conown & 0.810 & 0.144 & 0.817 & 0.131 & -0.007 & 0.571 \\
\hline
\end{tabular}




$\begin{array}{lcccrrl}\text { Instown } & 0.424 & 0.285 & 0.448 & 0.279 & -0.024 & 0.292 \\ \text { Stown } & 0.162 & 0.369 & 0.113 & 0.317 & 0.049 & 0.084^{*} \\ \text { Mgrown } & 0.193 & 0.277 & 0.234 & 0.308 & -0.041 & 0.080^{*} \\ \text { Age } & 3.579 & 0.410 & 3.487 & 0.366 & 0.092 & 0.004^{* * *} \\ \text { Zscore } & 2.260 & 1.766 & 2.232 & 1.385 & 0.028 & 0.834 \\ \text { Leverage } & 0.564 & 0.211 & 0.545 & 0.202 & 0.019 & 0.254 \\ \text { Finance } & 0.352 & 0.406 & 0.354 & 0.365 & 0.002 & 0.942 \\ \text { Growth } & 0.534 & 1.907 & 0.222 & 0.893 & 0.312 & 0.019^{* *} \\ \text { ROA } & 0.130 & 0.150 & 0.141 & 0.152 & 0.011 & 0.396 \\ \text { Size (Ln assets) } & 14.431 & 1.444 & 14.181 & 1.372 & 0.250 & 0.029^{* *} \\ \text { Accrual } & 0.011 & 0.143 & 0.007 & 0.153 & 0.004 & 0.714 \\ \text { Weak } & 0.350 & 0.477 & 0.235 & 0.425 & 0.115 & 0.002^{* * *} \\ \text { Big } & 0.236 & 0.424 & 0.227 & 0.419 & 0.009 & 0.801 \\ \text { Spec } & 0.319 & 0.466 & 0.406 & 0.492 & -0.087 & 0.024^{* *}\end{array}$

Note: This table presents the descriptive statistics for the variables used in the main analysis.

$*, * *, * *$ Significant at 10, 5 and 1 percent levels, respectively. See Table 2 for variable definitions.

Table 4, Spearman rank correlation matrix

\begin{tabular}{|c|c|c|c|c|c|c|c|c|c|c|c|c|c|}
\hline & (1) & (2) & (3) & (4) & (5) & (6) & (7) & (8) & (9) & (10) & (11) & (12) & (13) \\
\hline (1) & 1.00 & & & & & & & & & & & & \\
\hline (2) & -0.18 & 1.00 & & & & & & & & & & & \\
\hline (3) & -0.15 & 0.11 & 1.00 & & & & & & & & & & \\
\hline (4) & -0.06 & 0.06 & -0.10 & 1.00 & & & & & & & & & \\
\hline (5) & -0.04 & 0.08 & 0.05 & -0.13 & 1.00 & & & & & & & & \\
\hline (6) & 0.05 & 0.09 & 0.05 & -0.01 & 0.10 & 1.00 & & & & & & & \\
\hline (7) & -0.05 & 0.07 & -0.07 & 0.21 & -0.02 & 0.25 & 1.00 & & & & & & \\
\hline (8) & 0.08 & -0.05 & -0.06 & -0.00 & 0.06 & -0.10 & -0.10 & 1.00 & & & & & \\
\hline (9) & -0.00 & -0.13 & 0.02 & -0.03 & 0.06 & 0.07 & 0.07 & -0.05 & 1.00 & & & & \\
\hline (10) & -0.04 & 0.02 & 0.03 & -0.15 & 0.09 & 0.01 & -0.03 & 0.03 & 0.23 & 1.00 & & & \\
\hline (11) & 0.06 & -0.15 & 0.02 & -0.07 & 0.00 & -0.02 & -0.17 & -0.07 & -0.11 & -0.13 & 1.00 & & \\
\hline (12) & -0.03 & 0.00 & -0.05 & 0.02 & -0.02 & -0.19 & -0.04 & 0.11 & 0.18 & -0.02 & -0.17 & 1.00 & \\
\hline (13) & 0.12 & -0.10 & 0.04 & 0.04 & -0.05 & -0.01 & -0.09 & -0.01 & -0.21 & -0.11 & 0.18 & -0.05 & 1.00 \\
\hline (14) & -0.03 & 0.08 & 0.00 & 0.02 & 0.05 & 0.04 & 0.03 & -0.01 & 0.10 & 0.07 & -0.04 & 0.01 & -0.05 \\
\hline (15) & 0.04 & -0.10 & 0.00 & -0.08 & -0.10 & -0.16 & -0.15 & 0.06 & -0.04 & -0.14 & 0.12 & 0.12 & -0.03 \\
\hline (16) & -0.03 & 0.03 & 0.00 & 0.13 & 0.06 & 0.10 & 0.19 & -0.15 & 0.19 & 0.03 & -0.03 & 0.01 & -0.02 \\
\hline (17) & 0.04 & 0.06 & 0.06 & -0.00 & -0.01 & 0.02 & 0.02 & -0.01 & 0.03 & 0.00 & -0.05 & 0.01 & -0.05 \\
\hline (18) & -0.02 & 0.08 & 0.07 & 0.08 & 0.08 & 0.11 & 0.16 & -0.02 & 0.18 & 0.13 & -0.11 & 0.06 & 0.01 \\
\hline (19) & 0.09 & -0.09 & 0.04 & 0.02 & 0.12 & 0.20 & 0.09 & 0.01 & 0.04 & -0.01 & 0.22 & -0.04 & 0.00 \\
\hline (20) & 0.03 & 0.07 & 0.07 & 0.00 & 0.00 & 0.03 & 0.01 & 0.05 & 0.00 & 0.07 & -0.05 & 0.02 & 0.02 \\
\hline (21) & 0.11 & -0.05 & -0.13 & 0.01 & 0.00 & -0.01 & -0.03 & 0.02 & -0.01 & 0.01 & -0.01 & 0.00 & -0.01 \\
\hline (22) & 0.00 & -0.11 & 0.09 & -0.04 & -0.06 & 0.02 & 0.03 & 0.02 & 0.03 & 0.03 & 0.19 & 0.09 & 0.21 \\
\hline (23) & -0.08 & 0.03 & 0.01 & 0.04 & -0.01 & 0.10 & 0.05 & -0.00 & 0.07 & -0.08 & 0.22 & 0.02 & 0.08 \\
\hline & (14) & (15) & (16) & (17) & (18) & (19) & (20) & (21) & (22) & (23) & & & \\
\hline (14) & 1.00 & & & & & & & & & & & & \\
\hline (15) & -0.35 & 1.00 & & & & & & & & & & & \\
\hline (16) & 0.26 & -0.22 & 1.00 & & & & & & & & & & \\
\hline (17) & -0.49 & -0.06 & 0.11 & 1.00 & & & & & & & & & \\
\hline (18) & 0.75 & -0.53 & 0.42 & 0.38 & 1.00 & & & & & & & & \\
\hline (19) & -0.09 & 0.05 & 0.14 & -0.03 & 0.04 & 1.00 & & & & & & & \\
\hline (20) & 0.45 & -0.33 & -0.34 & 0.30 & 0.56 & -0.00 & 1.00 & & & & & & \\
\hline (21) & -0.04 & -0.02 & -0.05 & -0.11 & -0.05 & -0.00 & -0.03 & 1.00 & & & & & \\
\hline (22) & -0.01 & 0.04 & -0.01 & -0.02 & 0.02 & 0.23 & 0.05 & -0.07 & 1.00 & & & & \\
\hline (23) & 0.11 & -0.00 & 0.06 & -0.02 & 0.12 & 0.17 & 0.04 & -0.02 & 0.54 & 1.00 & & & \\
\hline
\end{tabular}


Notes: 1, Restate, 2, Ac_fd. 3, Ac_indp. 4, Ac_exp. 5, Ac_size. 6, Board_size. 7, Board_indp. 8, CEOchair. 9, Conown. 10, Instown. 11, Stown. 12, Mgrown. 13, Age. 14, Zscore. 15, Leverage. 16, Finance. 17, Growth. 18, ROA. 19, Size. 20, Accrual. 21, Weak. 22. Big. 23, Spce.

Coefficients in bold are significant at 0.10 levels. See Table 2 for variable definitions.

\subsection{Regression results}

Table 5 indicates the details of the relationship between audit committee gender diversity and the incidence of restatement. Evidence reveals that audit committee gender diversity impacts the likelihood of restating the financial statements. In particular, the coefficient of audit committee gender diversity $\left(A c \_f d\right)$ is $(-0.730)$ and Z-Stat is equal -2.61 with a significance level of 0.01 , which shows that the presence of at least one female director on the audit committee has a negative relationship with restatements and thus the research hypothesis is supported. This finding is consistent with prior research on board gender diversity and restatement (Abbott et al. 2012; Wahid, 2018) and supports gender theory, because gender diversity is a factor of organizational success and information improvement (Carter et al., 2010). A reason for this implication can be that female directors are more risk averse (e.g., Francis et al., 2015), do not tolerate opportunistic behavior (Krishnan \& Parsons, 2008) and are inclined to reports of a high quality (Thiruvadi \& Huang, 2011).

Table 5, Main regression results and alternative measures of audit committee gender diversity

\begin{tabular}{|c|c|c|c|c|c|c|c|c|}
\hline Variable & Coefficient & Z-Stat & Coefficient & Z-Stat & Coefficient & Z-Stat & Coefficient & Z-Stat \\
\hline$A c \_f d$ & $-0.730 * * *$ & -2.61 & & & & & & \\
\hline$A c \_f p$ & & & $-2.169 * *$ & -2.46 & & & & \\
\hline$A c \_f b i$ & & & & & $-1.643 * *$ & -2.51 & & \\
\hline$A c \_f s i$ & & & & & & & $-1.152 * *$ & -2.54 \\
\hline$A c \_i n d p$ & $-0.783 * * *$ & -2.66 & $-1.899 * * *$ & -2.70 & $-1.891 * * *$ & -2.69 & $-1.886 * * *$ & -2.68 \\
\hline$A c \_$exp & -0.907 & -1.62 & -0.906 & -1.62 & -0.907 & -1.62 & -0.906 & -1.62 \\
\hline Ac_size & $-0.467 * *$ & -2.35 & $-0.463 * *$ & -2.50 & $-0.455^{* *}$ & -2.46 & $-0.450 * *$ & -2.43 \\
\hline Board_size & 0.355 & 1.30 & 0.355 & 1.30 & 0.355 & 1.30 & 0.355 & 1.30 \\
\hline Board_indp & -1.057 & -1.39 & -1.035 & -1.56 & -1.042 & -1.37 & -1.046 & -1.37 \\
\hline CEOchair & $0.601 * *$ & 2.44 & $0.597 * *$ & 2.42 & $0.598 * *$ & 2.43 & $0.598 * *$ & 2.43 \\
\hline Conown & -0.195 & -0.25 & -0.165 & -0.21 & -0.176 & -0.23 & -0.181 & -0.23 \\
\hline Instown & -0.282 & -0.81 & -0.285 & -0.82 & -0.284 & -0.81 & -0.283 & -0.81 \\
\hline Stown & -0.360 & -1.05 & -0.352 & -1.03 & -0.355 & -1.04 & -0.356 & -1.04 \\
\hline Mgrown & -0.299 & -0.84 & -0.298 & -0.83 & -0.299 & -0.83 & -0.299 & -0.83 \\
\hline Age & $0.899 * * *$ & 3.50 & $0.900 * * *$ & 3.51 & $0.899 * * *$ & 3.51 & $0.899 * * *$ & 3.50 \\
\hline Zscore & 0.020 & 0.19 & 0.023 & 0.22 & 0.022 & 0.21 & 0.022 & 0.20 \\
\hline Leverage & 0.211 & 0.37 & 0.209 & 0.36 & 0.210 & 0.36 & 0.210 & 0.37 \\
\hline Finance & 0.496 & 1.13 & 0.490 & 1.12 & 0.492 & 1.12 & 0.493 & 1.12 \\
\hline Growth & $0.159 *$ & 1.66 & $0.159 *$ & 1.66 & $0.159 *$ & 1.66 & $0.159 *$ & 1.66 \\
\hline$R O A$ & -0.898 & -0.61 & -0.930 & -0.63 & -0.919 & -0.62 & -0.914 & -0.62 \\
\hline Size & $0.275^{* * *}$ & 2.98 & $0.274 * * *$ & 2.97 & $0.274 * * *$ & 2.97 & $0.275^{* * *}$ & 2.97 \\
\hline Accrual & 1.500 & 1.25 & 1.490 & 1.25 & 1.495 & 1.25 & 1.496 & 1.25 \\
\hline Weak & $0.511 * *$ & 2.44 & $0.504 * *$ & 2.41 & $0.506 * *$ & 2.42 & $0.507 * *$ & 2.43 \\
\hline Big & 0.076 & 0.27 & 0.080 & 0.29 & 0.078 & 0.28 & 0.078 & 0.28 \\
\hline Spec & $-0.548 * *$ & -2.27 & $-0.555^{* *}$ & -2.30 & $-0.552 * *$ & -2.29 & $-0.551 * *$ & -2.28 \\
\hline Constant & -2.817 & -1.28 & -2.753 & -1.25 & -2.768 & -1.26 & -2.780 & -1.26 \\
\hline IndustryDum & Yes & & Yes & & 10 & & & \\
\hline
\end{tabular}




$\begin{array}{lcccc}\text { YearDum } & \text { Yes } & \text { Yes } & \text { Yes } & \text { Yes } \\ \text { LR }(\text { prob }) & 118.31 * * *(0.000) & 117.55^{* * *}(0.000) & 117.81^{* * *}(0.000) & 117.94 * * *(0.000) \\ \text { Pseudo } R^{2} & 0.1358 & 0.1349 & 0.1352 & 0.1354 \\ \text { N } & 683 & 683 & 683 & 683\end{array}$

$*, * *, * * *$ Significant at 10, 5 and 1 percent levels, respectively. See Table 2 for variable definitions.

In the following, the evidence demonstrates that there is a significant negative relationship between audit committee independence (Ac_indp) and audit committee size (Ac_size) with restatement. These results are consistent with prior research (Abbott et al., 2004; Carcello et al., 2011; Lary \& Taylor, 2012) and show that, with an increase in audit committee effectiveness, the likelihood of incorrect reporting decreases. Additionally, the evidence consistent with Abbott et al. (2012) demonstrates a significant positive relationship between CEO duality (CEOchair) and restatement which points to the fact that companies with weak corporate governance are more likely to restate their financial statements. Moreover, the findings also reveal that firm characteristics including firm age (Age), sales growth (Growth) and firm size (Size) are significantly associated with restatement. Furthermore, consistent with prior research, internal controls weakness (Weak) has a significant positive relationship with restatement (Plumlee \& Yohn, 2010) and the audit quality measured by hiring an industry specialist auditor (Spec) reduces restatement (Chin \& Chi, 2009).

\subsection{Robustness tests}

\subsubsection{Alternative measures of audit committee gender diversity}

To ensure the further robustness of our findings, we used three alternative measures of gender diversity on audit committees (see, Sial et al., 2018; Usman et al., 2018a), including: $A c \_f p$, $A c_{-} f b i$, and $A c_{-} f s i$. Ac_fp is the proportion of female directors on the audit committee, while $A c_{-} f b i$ and $A c_{-} f s i$ are two comprehensive measures of gender diversity on the audit committee measured using formulas from the Blau index (Blau, 1977) and the Shannon index (Shannon, 1948), respectively (see Table 2). Table 5 shows that the gender-diversity measures $\left(A c \_f p, A c \_f b i\right.$, and $\left.A c_{\_} f s i\right)$ remain significant and negative. These results are consistent with our main findings.

\subsubsection{Problem of Endogeneity}

Recently, research on boardroom gender diversity or board sub-committees gender diversity (i.e., on the compensation or audit committees) are more concerned about the endogeneity issues. For example, previous studies (Green \& Homroy, 2018; Wahid, 2018, Usman et al., 2018a; 2018b; Sial et al., 2018) noted that gender diversity can be an endogenous variable. Therefore, we use three procedures for mitigating endogeneity concerns. First, following the works of Usman et al (2018a, 2018b) and Sial et al. (2018), we use the one-year lagged audit committee gender diversity proxy because female directors need some time to affect firm performance. In Method- 1 of Table 6, the coefficient of $A c \_f d$ was significant and negative. These results are similar to our previous findings that gender-diverse audit committees reduce the likelihood of financial restatements. 
Second, we used instrumental variables and estimated our main regression via the probit model with endogenous. In line with Bruynseels and Cardinaels (2014), Usman et al (2018a, 2018b) and Sial et al. (2018), we used the two instrumental variables for gender diversity-i.e., lagged values and the industry average of audit committees' gender-diversity measures - that are most likely to meet the exclusion restriction (i.e., correlated with the decision to have female directors on the audit committee but not correlated with financial restatement). Method- 2 of Table 6 shows that the coefficients of $A c \_f d$ remain negative and significant. These results validate our main findings.

Third, we used the propensity-score-matching method (PSM) because firms with and without a gender-diverse audit committee may vary in characteristics and it may be the case that the incidence of financial restatements are due to these characteristics rather than due to audit committee gender diversity. In line with previous studies (see, Bugeja et al., 2016; Usman et al., 2018), PSM is based on the probability that a firm has at least one female director on its audit committee (Ac_fd) based on the firm size (Size), board size (Board_size), the proportion of female directors on the board (Board_fp), the proportion of independent directors on the board (Board_indp) and institutional ownership (Instown) [5]. Method-3 of Table 6 shows that the results based on PSM are consistent with our main findings in Table 5 [6]. Overall, the results show that our main findings have not been affected by endogeneity.

Table 6, Endogeneity test

\begin{tabular}{|c|c|c|c|c|c|c|}
\hline \multirow{3}{*}{$\begin{array}{l}\text { Method } \\
\text { Variable }\end{array}$} & \multicolumn{2}{|c|}{ (1) } & \multicolumn{2}{|c|}{ (2) } & \multicolumn{2}{|c|}{ (3) } \\
\hline & \multicolumn{2}{|c|}{ Lag of gender diversity } & \multicolumn{2}{|c|}{ Instrumental variables } & \multicolumn{2}{|c|}{ Propensity score matching } \\
\hline & Coefficient & Z-Stat & Coefficient & Z-Stat & Coefficient & Z-Stat \\
\hline$A c_{-} f d$ & $-0.719 * *$ & -2.31 & $-0.667 * *$ & -2.38 & $-5.851 * * *$ & -3.40 \\
\hline$A c \_i n d p$ & $-1.881 * *$ & -2.41 & $-0.938 * *$ & -2.03 & -4.537 & -1.22 \\
\hline$A c \_$exp & -0.800 & -1.26 & -0.408 & -1.11 & 2.992 & 0.79 \\
\hline Ac_size & $-0.468 * *$ & -2.27 & $-0.238 *$ & -1.91 & -0.823 & -0.60 \\
\hline Board_size & 0.400 & 1.25 & 0.220 & 1.25 & -0.855 & -0.53 \\
\hline Board_indp & -0.797 & -0.94 & -0.427 & -0.84 & -5.455 & -1.11 \\
\hline CEOchair & $0.695 * *$ & 2.54 & $0.383 * *$ & 2.39 & 0.788 & 0.76 \\
\hline Conown & -0.745 & -0.86 & -0.564 & -1.07 & -3.499 & -0.76 \\
\hline Instown & -0.059 & -0.15 & 0.014 & 0.06 & -1.117 & -0.61 \\
\hline Stown & -0.557 & -1.46 & -0.325 & -1.44 & -3.341 & -1.49 \\
\hline Mgrown & -0.262 & -0.64 & -0.110 & -0.45 & $-4.641 * *$ & -2.52 \\
\hline Age & $0.866 * * *$ & 2.94 & $0.505 * * *$ & 2.89 & -1.140 & -0.64 \\
\hline Zscore & 0.029 & 0.23 & 0.008 & 0.11 & $-2.521 * * *$ & -3.03 \\
\hline Leverage & -0.051 & -0.08 & -0.007 & -0.02 & $4.444 *$ & 1.79 \\
\hline Finance & 0.769 & 1.39 & 0.480 & 1.49 & $8.493 * * *$ & 2.66 \\
\hline Growth & 0.121 & 1.15 & 0.079 & 1.35 & $1.140 * *$ & 2.54 \\
\hline$R O A$ & -1.306 & -0.76 & -0.636 & -0.62 & -7.240 & -1.19 \\
\hline Size & $0.321 * * *$ & 3.04 & $0.170 * * *$ & 2.77 & -0.715 & 1.13 \\
\hline Accrual & 1.885 & 1.34 & 1.064 & 1.29 & $19.754 * * *$ & 2.90 \\
\hline Weak & $0.687 * * *$ & 2.87 & $0.411 * * *$ & 2.92 & 0.085 & 0.10 \\
\hline Big & 0.096 & 0.30 & -0.009 & -0.05 & 1.553 & 1.00 \\
\hline Spec & $-0.586 * *$ & -2.17 & $-0.282 *$ & -1.73 & $2.371 * *$ & 2.12 \\
\hline Constant & -3.647 & -1.44 & -2.028 & 1.41 & $36.726 * *$ & 2.20 \\
\hline IndustryDum & \multicolumn{2}{|c|}{ Yes } & \multicolumn{2}{|c|}{ Yes } & \multicolumn{2}{|c|}{ Yes } \\
\hline YearDum & \multicolumn{2}{|c|}{ Yes } & \multirow{2}{*}{\multicolumn{2}{|c|}{ Yes }} & \multicolumn{2}{|c|}{ Yes } \\
\hline LR (prob) & \multicolumn{2}{|c|}{$110.26 * * *(0.000)$} & & & \multicolumn{2}{|c|}{$74.23 * * *(0.000)$} \\
\hline
\end{tabular}




$\begin{array}{lccc}\text { Wald }(\text { prob }) & --- & 93.45^{* * *}(0.000) & -- \\ \text { Pseudo } R^{2} & 0.1569 & --- & 0.5159 \\ \text { N } & 541 & 541 & 106\end{array}$

$*, * *, * * *$ Significant at 10,5 and 1 percent levels, respectively. See Table 2 for variable definitions.

\subsection{Additional test}

\subsubsection{Independent female directors and financial expert}

Corporate governance research has determined that independence is the prerequisite for an effective independent oversight role by directors; and greater independence leads audit committee members to fulfill their oversight responsibilities more effectively (Kelin, 2002). Moreover, financial expert members of audit committees perform their oversight functions in the financial reporting process (such as detecting significant misstatements) also more effectively (Defond et al., 2005). Goodwin (2003) points out that, in addition to independence, audit committee members need to have accounting knowledge or a financial background, because financial expertise and independence lead to the enhancement of members' ability to monitor corporate performance and the financial reporting process. Existing evidence suggests that independent and financial expert directors can improve financial reporting quality through reducing financial restatements (Abbott et al., 2004; Carcello et al., 2011; Lary \& Taylor, 2012, Mohammad et al., 2018). Therefore, we expect that independent and financial expert female directors have a greater impact on the reduction in financial restatements, compared to the female executives and female directors who lack financial expertise. In this respect, we use dummy variables for independent female directors (Ac_findp) and financial expert female directors (Ac_fexp) to examine the effect of independent and financial expert female directors (Table 2 provides the definitions of these variables). The coefficients of $A c_{\_}$findp and $A c_{\_}$fexp in Table 7 are negative and significant. These results support prior literature and indicate that independent and financial expert female directors on audit committees are more strongly associated with the reduction in financial restatements.

Table 7, Regressions results of independent female directors and financial experts

\begin{tabular}{lcccc}
\hline Variable & Coefficient & Z-Stat & Coefficient & Z-Stat \\
\hline Ac_findp & $-1.425^{* * * *}$ & -4.24 & & \\
Ac_fexp & & & $-0.946^{* * *}$ & -2.95 \\
Ac_indp & & $-1.667^{* *}$ & -2.40 \\
Ac_exp & -0.732 & -1.32 & & \\
Ac_size & $-0.447^{* *}$ & -2.39 & $-0.411^{* *}$ & -2.25 \\
Board_size & 0.161 & 0.62 & 0.234 & 0.89 \\
Board_indp & -1.075 & -1.40 & -1.169 & -1.54 \\
CEOchair & $0.642^{* * *}$ & 2.62 & $0.533^{* *}$ & 2.17 \\
Conown & -0.434 & -0.56 & -0.200 & -0.26 \\
Instown & -0.303 & -0.87 & -0.226 & -0.66 \\
Stown & -0.502 & -1.47 & -0.359 & -1.06 \\
Mgrown & -0.088 & -0.25 & -0.289 & -0.81 \\
Age & $0.925^{* * *}$ & 3.60 & $0.873^{* * *}$ & 3.42 \\
Zscore & 0.006 & 0.06 & 0.018 & 0.17 \\
Leverage & 0.271 & 0.46 & 0.290 & 0.51 \\
Finance & 0.508 & 1.14 & 0.455 & 1.04 \\
Growth & $0.167^{*}$ & 1.71 & $0.160^{*}$ & 1.66
\end{tabular}




\begin{tabular}{|c|c|c|c|c|}
\hline$R O A$ & -0.599 & -0.40 & -0.882 & -0.60 \\
\hline Size & $0.270 * * *$ & 2.91 & $0.278 * * *$ & 3.02 \\
\hline Accrual & 1.462 & 1.22 & 1.526 & 1.28 \\
\hline Weak & $0.585 * * *$ & 2.80 & $0.517 * *$ & 2.49 \\
\hline Big & 0.018 & 0.07 & 0.146 & 0.53 \\
\hline Spec & $-0.496^{* *}$ & -2.06 & $-0.606^{* *}$ & -2.54 \\
\hline Constant & -3.170 & -1.46 & -3.106 & -1.45 \\
\hline IndustryDum & \multicolumn{2}{|c|}{ Yes } & \multicolumn{2}{|c|}{ Yes } \\
\hline YearDum & \multicolumn{2}{|c|}{ Yes } & \multicolumn{2}{|c|}{ Yes } \\
\hline LR (prob) & \multicolumn{2}{|c|}{$122.19 * * *(0.000)$} & \multicolumn{2}{|c|}{$117.05 * * *(0.000)$} \\
\hline Pseudo $R^{2}$ & \multicolumn{2}{|c|}{0.1402} & \multicolumn{2}{|c|}{0.1343} \\
\hline $\mathrm{N}$ & \multicolumn{2}{|c|}{683} & \multicolumn{2}{|c|}{683} \\
\hline
\end{tabular}

$*, * *, * * *$ Significant at 10,5 and 1 percent levels, respectively. See Table 2 for variable definitions.

\subsubsection{Audit committee gender diversity and auditor choice}

Aldamen et al. (2018) argues that the presence of females on audit committees increases the likelihood of hiring auditors of a greater quality. Furthermore, Lai et al. (2017) found that the presence of at least one female member on audit committees is associated with an increase in the likelihood of hiring higher quality auditors. Moreover, prior studies demonstrate that with the increase in audit quality, the likelihood of restatement decreases (Chin \& Chi, 2009; Jiang et al, 2015). Thus, we investigate whether audit committee gender diversity is associated with the likelihood of hiring industry specialist auditors as a measure of audit quality (Dunn \& Mayhew, 2004; Kang, 2014). Given the research evidence and the negative relationship between audit committee gender diversity and likelihood of restatement, it is expected that the presence of females on audit committee increases the probability of hiring industry specialist auditors. The evidence of Table 8 supports the hypothesis and indicates that there is a significant positive relationship between audit committee gender diversity measures and hiring industry specialist auditors. This finding is consistent with previous studies (Aldamen et al., 2018; Lai et al., 2017) and supports their results.

Table 8, Regressions results of audit committee gender diversity and auditor choice

\begin{tabular}{|c|c|c|c|c|c|c|}
\hline Variable & $\begin{array}{c}\text { Coefficient } \\
\text { [Z-Stat] }\end{array}$ & $\begin{array}{c}\text { Coefficient } \\
\text { [Z-Stat] }\end{array}$ & $\begin{array}{c}\text { Coefficient } \\
\text { [Z-Stat }]\end{array}$ & $\begin{array}{c}\text { Coefficient } \\
\text { [Z-Stat] }\end{array}$ & $\begin{array}{c}\text { Coefficient } \\
\text { [Z-Stat] }\end{array}$ & $\begin{array}{c}\text { Coefficient } \\
\text { [Z-Stat] }\end{array}$ \\
\hline$\overline{A c \_f d}$ & $\begin{array}{l}0.861 * * * \\
{[3.00]}\end{array}$ & & & & & \\
\hline$A c \_f p$ & & $\begin{array}{l}2.647 * * * \\
{[2.94]}\end{array}$ & & & & \\
\hline$A c \_f b i$ & & & $\begin{array}{l}1.983 * * * \\
{[2.96]}\end{array}$ & & & \\
\hline$A c_{-} f_{s i}$ & & & & $\begin{array}{l}1.383^{* * * *} \\
{[2.97]}\end{array}$ & & \\
\hline$A c \_$findp & & & & & $\begin{array}{l}1.163 * * * \\
{[3.31]}\end{array}$ & \\
\hline Ac_fexp & & & & & & $\begin{array}{l}0.648 * * \\
{[1.98]}\end{array}$ \\
\hline Control Variable & Yes & Yes & Yes & Yes & Yes & Yes \\
\hline IndustryDum & Yes & Yes & Yes & Yes & Yes & Yes \\
\hline YearDum & Yes & Yes & Yes & Yes & Yes & Yes \\
\hline LR & $150.11 * * *$ & $149.75^{* * * *}$ & $149.88 * *$ & $149.95^{* * *}$ & $151.90 * * *$ & $144.69 * * *$ \\
\hline [prob] & {$[0.000]$} & {$[0.000]$} & {$[0.000]$} & [0.000] & {$[0.000]$} & {$[0.000]$} \\
\hline Pseudo $R^{2}$ & 0.1700 & 0.1696 & 0.1697 & 0.1699 & 0.1720 & 0.1638 \\
\hline
\end{tabular}


Notes: According to prior research (Chaney et al. 2004; Kang, 2014; among others), we estimate the following logistic regression model for investigating the relationship between the presence of females on audit committees and auditor choice:

$$
\begin{aligned}
& \text { Spec }_{i t}=\beta_{0}+\beta_{1} A c \_f d_{i t}+\beta_{2} A c \_i n d p_{i t}+\beta_{3} A c_{-} \exp _{i t}+\beta_{4} A{ }_{4} \_s i z e_{i t}+\beta_{5} B o a r d \_s i z e_{i t} \\
& +\beta_{6} \text { Board_indp }_{i t}+\beta_{7} \text { CEOChair } r_{i t}+\beta_{8} \text { Conown }_{i t}+\beta_{9} \text { Instown }_{i t}+\beta_{10} \text { Stown }_{i t} \\
& +\beta_{11} \text { Mgrown }_{i t}+\beta_{12} \text { Leverage }_{i t}+\beta_{13} \text { ROA }_{i t}+\beta_{14} \text { Size }_{i t}+\beta_{15} \text { Loss }_{i t}+\beta_{16} \text { Chta }_{i t} \\
& +\beta_{17} \text { Aturn }_{i t}+\beta_{18} \text { Curr }_{i t}+\beta_{19} \text { Quick }_{i t}+\text { Industry Dummies }+ \text { Year Dummies }+\varepsilon_{i t}
\end{aligned}
$$

$*, * *, * * *$ Significant at 10,5 and 1 percent levels, respectively. See Table 2 for variable definitions

\section{Summary and conclusion}

In this study, we investigated the relationship between audit committee gender diversity and financial restatements. Using a sample of Iranian listed companies for the period 2013-2017, we found that the presence of at least one woman on the audit committee reduces the likelihood of financial restatement. Additionally, our findings indicate that independent and financial expert female directors on the audit committee are more strongly associated with the reduction in the likelihood of financial restatement. Moreover, our results reveal that audit committee gender diversity can increase the likelihood of hiring higher quality auditors.

The findings of this study make three important contributions. First, this study contributes to the growing literature on board gender diversity and financial restatements (Abbott et al., 2012; Wahid, 2018). Furthermore, previous studies examined the effects of audit committee characteristics (such as financial expertise, independence, size and the frequency of meetings) on financial statement restatements (e.g., Abbott et al., 2004; Carcello et al., 2011), but gender diversity as an audit committee characteristic was not examined. This being so, the present study bridges an important research gap by examining the effect of gender diversity on the audit committee, as one of the important subgroups of the board, on financial reporting. Apart from this, our study adds to the literature on the effect of board gender diversity on the selection of auditors of a higher quality (Lai et al., 2017). Second, by investigating the effect of independent and financial expert female directors, we contribute to the extant literature and provide new evidence on the more effective oversight role and greater ability of independent female directors and financial expert female directors, respectively, that is compared to female executives and female directors without financial expertise; which has been significantly disregarded in prior research. Furthermore, our findings are consistent with the literature on gender diversity which suggests that women perform better in a monitoring role, are more conservative and make more ethical decisions. Also, the results are inconsistent with critical mass theory and show that female directors are not merely tokens; even one female director can reduce the likelihood of financial restatement. Third, the practical implications of this study support the notion that gender diversity on the board and its subgroups such as the audit committee is an important issue in corporate governance. Considering our research findings, we suggest that the presence of female directors can improve corporate governance in developing countries, where governance and investor protection mechanisms are weak (e.g., Iran). In particular, the findings of this study send positive signals to the supervisors and policy makers in developing 
countries regarding recommending or requiring gender diversity in audit committee composition.

This study has some limitations which suggest directions for ongoing studies. First, we used data from an emerging market (Iran), so our findings may not be generalizable outside of Iran, and where the hypothesis must be tested further. In particular, in western countries, the presence of females in leadership and management positions is stronger than in Islamic countries (e.g., Iran). Regarding the low presence of females on audit committees in Iran, this study facilitates conducting future research on this topic in the other countries, where the presence of female directors on the boards and audit committees is stronger. Second, the fact that board gender diversity is not mandatory in the data we used, provides an opportunity to compare female directors' economic effect in countries that require gender diversity on the boards with those that do not impose such requirement. Our study contributes to the heated debate on whether mandatory and non-mandatory quotas for women in the boardroom lead to the same consequences. Finally, future research can investigate whether the other characteristics of females on boards and audit committees (such as tenure, education, age, etc.) can affect the likelihood of financial restatements. In addition, a promising scope for future research is a further investigation into the effect of female CEOs and CFOs on the likelihood of financial restatements in emerging markets, because they are directly engaged in management practices.

\section{Notes}

1. The annual reports of the companies in the TSE are available at the research, development and Islamic studies center (www.RDIS.ir/CompaniesReports.asp) and (www.Codal.ir).

2. The Rahavard-e-Novin database is the most comprehensive database in the Iranian capital market. The full version of this database contains financial reports and information on the capital market. It further provides various options for essential technical analysis (Hesarzadeh \& Bazrafshan, 2018).

3. Due to the improper disclosure of audit committee meetings, we are not able to control for the frequency of audit committee meetings variable in the model. Nonetheless, the three other variables of audit committee (independence, financial expertise and size) are controlled.

4. The international big audit firms (BIG4) have not set up their activities in Iran (see, Bagherpoor et al., 2014; MohamadRezaee \& Mohd-Saleh, 2018). The Audit Organization of Iran is a government entity which is known as the largest audit firm in Iran. Therefore, similar to Hesarzadeh and Bazrafshan (2018), we classify audit firms in two groups of big (the audit organization) and small (the other audit firms).

5. By obtaining the fitted values from the regression on the potential determinants of female directors on the audit committee, this paper matches each firm-year observation to another one with the closest fitted value (within 5 percent) in the same year and the same industry, following Lawrence et al. (2011) and Hesarzadeh and Bazrafshan (2018).

6. Ideally our sample should have comprised 172 firm-year observations (86 firm-year observations in each group), because in our full sample there were 86 firm-year observations with at least one female director on the audit committee. However, due to unavailability of a nearest neighbor for every firm-year observation, our sample is reduced to 106 firm-year observations (53 firm-year observations in each group). 


\section{References}

Abbott, L. J., Parker, S. and Presley, T. J. (2012), "Female board presence and the likelihood of financial restatement", Accounting Horizons, Vol. 26 No.4, pp. 607-629.

Abbott, L., Parker, S. and Peters, G. (2004), "Audit committee characteristics and restatements", Auditing: A Journal of Practice \& Theory, Vol. 23 No. 1, pp. 69-87.

Abdullah, S. N., Yusof, N. Z. M. and Nor, M. N. M. (2010), "Financial restatements and corporate governance among Malaysian listed companies", Managerial Auditing Journal, Vol. 25 No. 6, pp. 526-552.

Adams, R. B. and Ferreira, D. (2009), "Women in the boardroom and their impact on governance and performance", Journal of Financial Economics, Vol. 94 No. 2, pp. 291-309.

Agrawal, A. and Chadha, S. (2005), "Corporate Governance and Accounting Scandals", Journal of Law \& Economics, Vol. 48 No. 2, pp. 371-406.

Akhigbe, A., Kudla, R. J. and Madura, J. (2005), "Why are some corporate earnings restatements more damaging", Applied Financial Economics, Vol. 15 No. 5, pp. 327-336.

Aldamen, H., Hollindale, J. and Ziegelmayer, J. L. (2018), "Female audit committee members and their influence on audit fees", Accounting and Finance, Vol. 58 No. 1, pp. 57-89.

Almer, E. D., Gramling, A. A. and Kaplan, S. E. (2008), "Impact of post-restatement actions taken by a firm on non-professional investors' credibility perceptions", Journal of Business Ethics, Vol. 80 No. 1, pp. 61-76.

Anderson, R. C., Mansi, S. A. and Reeb, D. M. (2004), "Board characteristics, accounting report integrity, and cost of debt", Journal of Accounting and Economics, Vol. 37 No. 3, pp. 315342.

Arun, T. G., Almahrog, Y. E. and Aribi, Z. H. (2015), "Female directors and earnings management: Evidence from UK companies", International Review of Financial Analysis, Vol. 39 No. 1, pp. 137-146.

Bagherpour, M., Monroe, G. and Shailer, G. (2014), "Government and managerial influence on auditor switching under partial privatization", Journal of Accounting and Public Policy, Vol. 33 No. 4, pp. 372-390.

Bart, C., and McQueen, G. (2013), "Why women make better directors", International Journal of Business Governance and Ethics, Vol. 8 No 1, pp. 93-99.

Barua, A., Davidson, L. F., Rama, D. V. and Thiruvadi, S. (2010), "CFO gender and accruals quality", Accounting Horizons, Vol. 24 No. 1, pp. 25-39.

Beasley, M. S. (1996), "An empirical analysis of the relation between the board of director composition and financial statement fraud", The Accounting Review, Vol. 71 No. 4, pp. 443465.

Beckmann, D., and Menkhoff, L. (2008), "Will women be women? Analyzing the gender difference among financial experts", Kyklos, Vol. 61 No. 3, pp. 364-384.

Bellucci, A., Borisov, A. and Zazzaro, A. (2010), "Does gender matter in bank-firm relationships? Evidence from small business lending", Journal of Banking \& Finance, Vol. 34 No. 12, pp. 2968-2984.

Blau, P.M. (1977), Inequality and Heterogeneity, The Free Press, New York, NY.

Bohren, O., and Strom, R. (2010), "Governance and Politics: Regulating Independence and Diversity in the Board Room", Journal of Business Finance \& Accounting, Vol. 37 No. 9/10, pp. 12811308 . 
Bugeja, M., Matolcsy, Z. and Spiropoulos, H. (2016), "The association between gender-diverse compensation committees and CEO compensation", Journal of Business Ethics, Vol. 139 No. 2, pp. 375-390.

Campbell, K., and Minguez-Vera, A. (2008), "Gender Diversity in the Boardroom and Firm Financial Performance", Journal of Business Ethics, Vol. 83 No. 3, pp. 435-451.

Carcello, J, V., Neal, T, L., Palmrose, Z. V. and Scholz, S. (2011), "CEO Involvement in Selecting Board Members, Audit Committee Effectiveness, and Restatements", Contemporary Accounting Research, Vol. 28 No. 2, pp. 396-430.

Carter, D. A., Simkins, B. J. and Simpson W. G. (2003), "Corporate governance, board diversity, and firm value", Financial Review, Vol. 38 No. 1, pp. 33-53.

Carter, D. A., Souza, F. D., Simkins, B.J. and Simpson, W.G. (2010), "The gender and ethnic diversity of US boards and board committees and firm financial performance", Corporate Governance: An International Review, Vol. 18 No. 5, pp. 396-414.

Carver, B.T., Cline, B. and Hoag, M. (2013), "Underperformance of founder-led firms: an examination of compensation contracting theories during the executive stock options backdating scandal", Journal of Corporate Finance, Vol. 23, No (December), pp. 294-310.

Casterella, J. R., Francis, J. R., Lewis, B. L. and Walker, P. L. (2004), "Auditor industry specialization, client bargaining power, and audit pricing", Auditing: A Journal of Practice \& Theory, Vol. 23 No. 1, pp. 123-140.

Chan, A. M., Liu, Y. G. and Sun, J. (2013), "Independent audit committee members' board tenure and audit fees", Accounting and Finance, Vol. 53 No. 4, pp. 1129-1147.

Chapple, L., and Humphrey, J. E. (2014), "Does board gender diversity have a financial impact? Evidence using stock portfolio performance", Journal of Business Ethics, Vol. 122 No. 4, pp. 709-723.

Chen, K. Y., Elder, R J. and Hung, Sh. (2014), "Do post-restatement firms care about financial credibility? Evidence from the pre- and post-SOX eras", Journal of Accounting Public Policy, Vol. 33 No. 2, pp. 107-126.

Chen, Y., Eshleman, J, D. and Soileau, J, S. (2016), "Board Gender Diversity and Internal Control Weaknesses", Advances in Accounting, Vol. 33 No (June), pp. 11-19.

Chin, CL., and Chi, H. Y. (2009), "Reducing restatement with Increased Industry Expertise", Contemporary Accounting Research, Vol. 26 No. 3, pp. 729-765.

Czerney, K., Schmidt, J. and Thompson, A. M. (2013), "Does Auditor Explanatory Language in Unqualified Audit Reports Indicate Increased Financial Misstatement Risk", The Accounting Review, Vol. 89 No. 6, pp. 2115-2149.

Davidson, R., Xie, B. and Xu, W. (2004), "Market reaction to voluntary announcements of audit committee appointments: The effect of financial expertise", Journal of Accounting and Public Policy, Vol. 23 No. 1, pp. 116-147.

Davies, E. W. (2011), "Women on boards", https://www.gov.uk/government/uploads/system/ uploads/attachment_data/file/31480/11-745-women-on-boards.pdf.

Dawson, L. (1997), "Ethical Difference between men and women in sales profession", Journal of Business Ethics, Vol. 16 No. 1, pp. 1143-1152.

DeAngelo, L. (1981), "Auditor size and audit quality", Journal of Accounting and Economics, Vol. 3 No 3, pp. 183-199.

DeFond, M., and Jiambalvo, J. (1991), "Incidence and circumstances of accounting errors", The Accounting Review, Vol. 66 No. 3, pp. 643-655.

Defond, M., Hann, R., and Hu, X. (2005), "Does market value financial expertise on audit committees of board of directors?" Journal Accounting Research, Vol. 43 No. 2, pp. 153-193. 
Demirkan, S., and Fuerman, R. D. (2014), "Auditor litigation: Evidence that revenue restatements are determinative", Research in Accounting Regulation, Vol. 26 No2, pp. 164-174.

Dey, A. (2008), "Corporate Governance and Agency Conflicts", Journal of Accounting Research, Vol. 46 No. 5, pp. 1143-1181.

Dunn, K. A., and Mayhew. B. W. (2004), "Audit firm industry specialization and client disclosure quality", Review of Accounting Studies, Vol. 9 No. 1, pp. 35-58.

Efendi, J., Srivastava, A. and Swanson, E. P. (2007), "Why do Corporate Managers Misstate Financial Statements?" The Role of Option Compensation and Other Factors", Journal of Financial Economics, Vol. 85 No. 3, pp. 667-708.

Eilifsen, A., and Messier, W. F. (2000), "The incidence and detection of misstatements: A review and integration of archival research", Journal of Accounting Literature, Vol. 19 No. 1, pp. 1-43.

Fakhari, H., Rezaei Pitenoei, Y. (2018), "The impact of audit committee on the companies information environment", Management Accounting, Vol. 11 No. 36, pp. 63-79. (in Persian)

Francis, B., Hasan, I., Park, J. C. and Wu, Q. (2015), "Gender Differences in Financial Reporting Decision Making: Evidence from Accounting Conservatism", Contemporary Accounting Research, Vol. 32 No. 3, pp. 1285-1318.

Geiger, M., and Connell, B. (1999), " Accounting student ethical perceptions: An analysis of training and gender effects, Teaching Business Ethics, Vol. 2 No. 4, pp. 371-388.

Geiger, M., and Connell, B. (1999), "Governance associated with the revelation of internal control material weaknesses and their subsequent remediation", Contemporary Accounting Research, Vol. 28 No. 1, pp. 331-383.

General Accounting Office. (2002), "financial statement restatements: Trends, market impacts, regulatory responses and remaining challenges", GAO-03-138 (Washington, D.C).

Goodwin, J. (2003), "The relationship between the audit committee and the internal audit function: evidence from Australia and New Zealand", International Journal of Auditing, Vol. 7, No. 3, pp. 263-278.

Green, C. P., and Homroy, S. (2018), "Female directors, board committees and firm performance", European Economic Review, Vol. 102, pp. 19-38.

Grosvold, J., Brammer, S. and Rayton, B. (2007), "Board diversity in the United Kingdom and Norway: an exploratory analysis", Business Ethics: An European Review, Vol. 16 No. 4, pp. 344-57.

Gul, F. A., Hutchinson, M. and Lai, K. M. (2013), "Gender-diverse boards and properties of analyst earnings forecasts", Accounting Horizons, Vol. 27 No. 3, pp. 511-538.

Gul, F. A., Srinidhi, B. and Ng, A. C. (2011), "Does gender diversity improve the informativeness of stock prices", Journal of Accounting and Economics, Vol. 51, No. 3, pp. 314-38.

Habib, A., and Azim, I. (2008), "Corporate governance and the value relevance of accounting Information", Accounting Research Journal, Vol. 21 No. 2, pp. 167-194.

Hafsi, T., and Turgut, G. (2013), "Boardroom Diversity and Its Effect on Social Performance: Conceptualization and Empirical Evidence," Journal of Business Ethics, Vol. 12 No. 3, pp. 463-479.

Harjoto, M. A., Laksmana, I. and Lee, R. (2015), "The impact of demographic characteristics of CEOs and directors on audit fees and audit delay", Managerial Auditing Journal, Vol. 30 No. 8/9, pp. 963-997.

Hennes, K., Leone, A. and Miller. B. (2008), "The importance of distinguishing errors from irregularities in restatement research: The case of restatements and CEO/CFO turnover", The Accounting Review, Vol. 83 No. 6, pp. 1487-1519. 
Hesarzadeh, R. (2018), "Are the individual and collective roles of financial reporting quality measures the same? Evidence in the context of information uncertainty", Spanish Journal of Finance and Accounting, Vol. 48 No. 2, 160-202.

Hesarzadeh, R., and Bazrafshan, A. (2018), "Corporate reporting readability and regulatory review risk", Baltic Journal of Management, Vol. 13 No. 4, pp.488-507.

Huang, J., and Kisgen, D. J. (2013), "Gender and corporate finance: Are male executives overconfident relative to female executives", Journal of Financial Economics, Vol. 108 No. 3, pp. 822-839.

Huse, M., and Solberg, A. (2006), "Gender-related Boardroom Dynamics: How Scandinavian Women Make and can Make Contributions on Corporate Board", Women in Management Review, Vol. 21 No. 2, pp. 113-130.

Huse, M., Nielsen, S. and Hagen, I. (2009), "Women and Employee-elected Board Members, and their Contributions to Board Control Tasks", Journal of Business Ethics, Vol. 89 No. 4, pp. 581-597.

Imani, M., Abdi, M., Kazemi Olum, M. (2017), "Investigating the impact of gender diversity in the audit committee on the audit fees of companies listed in Tehran Stock Exchange", Journal of Accounting and Auditing Review, Vol. 24 No. 3, pp. 303-322. (in Persian)

Ittonen, K., Miettinen, J. and Vahamaa, S. (2010), "Does female representation on audit committees affect audit fees", Quarterly Journal of Finance and Accounting, Vol. 49 No. 3/4, pp. 113139.

Jiang, H., Habib, A. Zhou, D. (2015), "Accounting restatements and audit quality in China", Advances in Accounting, Vol. 31 No. 1, pp. 125-135.

Joecks, J., Pull, K. and Vetter, K. (2013), "Gender diversity in the boardroom and firm performance: What exactly constitutes a "critical mass? ", Journal of Business Ethics, Vol. 118 No. 1, pp. 61-72.

Klein, A. (2002), "Audit committee, board of director characteristics, and earnings management", Journal of Accounting and Economics, Vol. 33 No. 3, pp. 375-400.

Konrad, A. M., Kramer, V. and Erkut, S. (2008), "Critical mass: The impact of three or more women on corporate boards", Organizational Dynamics, Vol. 37 No. 2, pp. 145-164.

Kordestani, G., Azad, A. and Kazemi, M. (2011), "Experimental review of the materiality of prior period adjustments" Accounting Research, Vol. 2 No. 8, pp. 63-72. (in Persian)

Krishnan, G. V., and Parsons, L. M. (2008), "Getting to the bottom line: An exploration of gender and earnings quality", Journal of Business Ethics, Vol. 78 No. 1/2, pp. 65-76.

Krishnan, G., and Visvanathan, G. (2009), "Do auditors price audit committee's expertise? The case of accounting versus non-accounting financial experts", Journal of Accounting, Auditing and Finance, Vol. 24 No. 1, pp. 115-144.

Krishnan, J. (2005), "Audit committee quality and internal control: An empirical analysis", The Accounting Review, Vol. 80 No. 2, pp. 649-675.

Krishnan, J., Yuan, W. and Wanli, Z. (2011), "Legal expertise on corporate audit committees and financial reporting quality", The Accounting Review, Vol. 86 No. 6, pp. 2099-2130.

Lai, K, M, Y., Srinidhi, B., Gul, F, A., and Tsui, J, S, L. (2017), "Board gender diversity, auditor fees, and auditor choice", Contemporary Accounting Research, Vol. 34 No. 3, pp. 1681-1714.

Lary, A. M., and Taylor, D. W. (2012), "Governance characteristics and role effectiveness of audit committees", Managerial Auditing Journal, Vol. 27 No. 4, pp. 336-354.

Lawrence, A., Minutti-Meza., M. and Zhang., P. (2011), "Can Big 4 versus non-Big 4 differences in audit quality proxies be attributed to client characteristics?", The Accounting Review, Vol. 86 No. 1, pp. 259-286. 
Luckerath-Rovers, M. (2010), "Women on Board and Firm Performance", Journal of Management \& Governance, Vol. 17 No. 2, pp. 491-509.

Mashayekhi, B., and Bazaz, M. S. (2008), "Corporate governance and firm performance in Iran", Journal of Contemporary Accounting and Economics, Vol. 4 No. 2, pp. 156-172.

McMullen, D. A., and Raghunandan, K. (1996), "Enhancing audit committee effectiveness", Journal of Accountancy, Vol. 182 No. 2, pp. 79-81.

Ming, C. H., and Eam, L. K. (2016), "Estimating the nonlinear effects of female directors on financial performance: The case of Malaysian initial public offering companies", Gender in Management: An International Journal, Vol. 31 No. 2, pp. 97-113.

Mohammad, W, M, W., Wasiuzzaman, S., Morsali, S, SH., and Zaini, R, M. (2018), "The Effect of Audit Committee Characteristics on Financial Restatements in Malaysia", Journal of AsiaPacific Business, Vol. 19 No. 1, pp. 4-22.

MohammadRezaei, F., and Mohd-Saleh, N. (2018), "Audit report lag: The role of auditor type and increased competition in the audit market", Accounting and Finance, Vol. 58 No. 3, pp. 885920.

MohammadRezaei, F., Mohd-Saleh, N., and Ahmed, K. (2018), "Audit firm ranking, audit quality and audit fees: Examining conflicting price discrimination views", International Journal of Accounting, Vol. 53 No. 4, pp. 295-313.

Nikbakht, M. R., and Rafiee, A. (2013), "A model of effective factors in financial restatements in Iran", Vol. 3 No. 9, pp. 167-194. (in Persian).

Oradi, J., Lari, D, B., Salari, F, Z., (2016), "Exploring the relationship between audit committee characteristics and the firm performance", Accounting Empirical Research of Financial, Vol. 3 No. 4, pp. 131-152. (in Persian)

Oradi, J., Salehi, M., Salari, F, Z., (2016), "The effects of presence of audit committee and its characteristics on audit report", Journal of Accounting Knowledge, Vol. 7 No. 26, pp. 59-83. (in Persian)

Palmrose, Z. V., Richardson, V. and Scholz, S. (2004), "Determinants of market reactions to restatement announcements", Journal of Accounting and Economics, Vol. 37 No. 1, pp. 5989.

Plumlee, M., and Yohn, T. L. (2010), "An analysis of the underlying causes attributed to restatements", Accounting Horizons, Vol. 24 No.1, pp. 41-64.

Rezazadeh, J., Abdi, M., Kazemi Olum, M. (2017), "Audit committee characteristics and financial restatements", Journal of Financial Accounting Research, Vol. 9 No. 3, pp. 1-16. (in Persian)

Rosener, J. (1990), "Ways Women Lead", Harvard Business Review, Vol. 68 No. 6, pp. 119-125.

Schubert, R. (2006), "Analyzing and managing risks - on the importance of gender differences in risk attitudes", Managerial Finance, Vol. 32 No. 9, pp. 706-715.

Shannon, C.E. (1948), "A mathematical theory of communication", Bell System Technical Journal, Vol. 27 No. 1, pp. 379-423.

Sial, M., Zheng, C., Cherian, J., Gulzar, M, A., Thu, P, A., Khan, T, A., and Khuong, N, V. (2018), "Does corporate social responsibility mediate the relation between boardroom gender diversity and firm performance of Chinese Listed Companies?" Sustainability, Vol. 10 No. 10, pp. 1-18.

Soltana, N., Harjinder, S. and Vander, Z. (2015), "Audit committee characteristics and audit report lag', Intarnational Journal of Auditing, Vol. 19 No. 2, pp. 72-87.

Srinidhi, B., Gul. F. and Tsui, J. (2011), "Female directors and earnings quality", Contemporary Accounting Research, Vol. 28 No. 5, pp. 1610-1644.

Tehran Stock Exchange. (2013), "Internal control instruction", https://www.seo.ir/Page/RnfRqDyvXjR4uFy3BtquPw/. 
Thiruvadi, S., and Huang, H. W. (2011), "Audit committee gender differences and earnings management", Gender in Management: An International Journal, Vol. 26 No. 7, pp. 483498.

Thorne, L., Massey, D. and Magnan, M. (2003), "Institutional context and auditors' moral reasoning: A Canada-U.S. Comparison", Journal of Business Ethics, Vol. 43 No. 4, pp. 305-321.

Torchia, M., Calabrò, A., and Huse, M. (2011), "Women directors on corporate boards: From tokenism to critical mass", Journal of Business Ethics, Vol. 102 No. 2, pp. 299-317.

Usman, M. Farooq, M.U., Zhang, J., Makki, A.M.M. and Sun, J. (2018c), "She-E-Os and the Cost of Debt: Do female CEOs pay less for credit?", The B.E. Journal of Economic Analysis and Policy, https://doi.org/10.1515/bejeap-2018-0177.

Usman, M. Zhang, J., Farooq, M.U., Makki, A.M.M., and Dong, N. (2018a), "Female Directors and CEO Power", Economics Letters, Vol. 165 (April), pp. 44-47.

Usman, M. Zhang, J., Wang, F., Sun, J., and Makki, A.M.M., (2018b), "Gender diversity in compensation committees and CEO pay: Evidence from China", Management Decision, Vol. 56 No. 5, pp. 1065-1087.

Wahid, A. S. (2018), "The Effects and the Mechanisms of Board Gender Diversity: Evidence from Financial Manipulation", Journal of Business Ethics, https://doi.org/10.1007/s10551-0183785-6.

Wang, X., and Wu, M. (2011), "The quality of financial reporting in China: An examination from an accounting restatement perspective", China Journal of Accounting Research, Vol. 4 No. 4, pp. 167-196.

Waring, M. (1988), "If Women Counted: A New Feminist Economics", Harper \& Row, San Francisco, CA.

Westphal, J., and Milton, L. (2000), "How Experience and Network Ties Affect the Influence of Demographic Minorities on Corporate Boards," Administrative Science Quarterly, Vol. 45 No. 2, pp. 366-398.

Wilson, W. M. (2008), "An empirical analysis of the decline in the information content of earnings following restatements", The Accounting Review, Vol. 83 No. 2, pp. 519-548.

Wood, W., Polek, D. and Aiken, C. (1985), "Sex differences in group task performance", Journal of Personality and Social Psychology, Vol. 48 No. 1, pp. 63-71.

Xie, B., Davidson, W. N. and Dadalt, P. G. (2003), "Earnings management and corporate governance: the role of the board and the audit committee", Journal of Corporate Finance, Vol. 9 No. 3, pp. 295-316.

Zahra, S. A., and Pearce, J. A. (1989), "Boards of directors and corporate Financial Performance: A Review and Interactive Model", Journal of Management, Vol. 15 No. 2, pp. 291-334.

Zhang, H., Huang, H. G. and Habib, A. (2018), "The Effect of Tournament Incentives on Financial Restatements: Evidence from China", The International Journal of Accounting, Vol. 53 No. 2, pp. 118-135.

Zhang, Y., Zhou, J. and Zhou, N. (2007), "Audit committee quality, auditor independence, and internal control weaknesses", Journal of Accounting and Public Policy, Vol. 26 No. 3, pp. 300-327. 